\title{
Is a Board of Directors Really Necessary?
}

\author{
Kathleen Allen (University of Southern California)
}

KEYWORDS: Entrepreneurship, Leadership, Startups, mentors.

Arguably, no CEO anywhere doesn't occasionally wish that he or she didn't have to deal with a board of directors. You're the CEO! The visionary leader! This is your baby, and you and your management team know best what the business needs. Besides, it takes a lot of precious time to prepare for a board meeting-time that could be spent working on the business.

All that may be true, but the reality is if you take investment capital from venture capitalists (VCs) or many other investor types to start and grow your business, you will need a corporate legal form and that means you'll be dealing with a board of directors. VCs generally do not like LLCs or S-Corps because these organizational forms pass taxable income through to the owners in proportion to their level of ownership. As a result, LLCs and S-Corps offer a level of complexity that VCs would rather avoid. Perhaps a bigger reason is that only C-Corps can offer the preferred stock that VCs want in exchange for the risk they're taking because it puts them first in line to get paid in a liquidation.

While a board may require some adjustment and compromise, wise CEOs ultimately see them as a valuable resource rather than a necessary evil. The key is learning to work with them productively.

\section{Expertise Should be Tapped}

In the early stages of a company, the board will generally consist of the founders, any investors and others who can open doors for the new venture. It's the board's job to hire or fire the CEO, approve any major transactions and set the compensation for the executive team. In a startup, the board, if constituted well, will also be an invaluable source of knowledge and advice to the CEO.

Unfortunately, many entrepreneurs talk about their boards as if they were simply something to be tolerated (they invested in us so I guess they should have a seat at the table). Others think of their boards as cheerleaders and rubber stampers, not challengers. The reality is that most newly minted entrepreneurs have no idea how to deal with the board effectively or how to prepare for and behave in a board meeting. As a consequence, they generally don't take advantage of the expertise sitting in the room -- or worse, they make themselves look incompetent by not preparing adequately for the meeting.

\section{How to Make Your Board Happy}

Working with a board of directors will occasionally be challenging, and they will test you. But if you set some standards for your interactions with them, your company will come out ahead. Here are some ways you can work productively with your board.

\section{Come prepared and respect their time.}

The best way to prepare for a board meeting is to run your business. You have milestones to achieve and that's your number one priority. Having said that, you do need to prepare a board packet that respects both your time and the board members' time (see \#2). Send a board packet out several days before the meeting so your board has time to review what will be covered and give some thought to ways they can help you. Board meetings vary in length depending on what is happening with the company. Regularly scheduled meetings (monthly, quarterly) can last several hours up to a few days and include dinner and other meals. Shorter meetings can be accomplished via telephone or video conference, while longer meetings are typically held at the company's headquarters. Whatever the length of the meeting, start with what you accomplished since the last meeting and what you plan to achieve before the next board meeting. Have the facts and justification at your fingertips so you look professional and don't waste time.

\section{Prepare what the board wants to see.}

After the call to order (Roberts' Rules of Order), it's time to deal with the materials you sent to the board. 
Entrepreneurs often start with highlights of accomplishments since the previous meeting and some challenges that might be looming. Some entrepreneurs prepare a "dashboard," which is simply a one-page (or one-slide) summary of the key metrics that characterize the health of the business-particularly cash flow. The numbers are organized by actual numbers from the previous month, the current numbers and the plan for the next month (or quarter, depending on how often your board meets). The board will also want to hear reports on product development, operations, financials and human resources. In general, most of this should be in the board materials (generally a readable PowerPoint deck) you distributed in advance of the meeting. Directors typically review those materials carefully before the meeting, so don't bore them during the meeting by reiterating word-by-word everything you said in the materials. Instead, summarize key points and ask for questions and comments.

\section{Don't surprise the board with bad news.}

Let's face it: at times you have less-than-favorable news to share with your board. You don't need to share everything. For example, your board does not need to know that you let go of a non-executive employee; missed a deadline for a non-critical project; or about other negative situations that you quickly got under control. However, if a key executive leaves or the company misses projected earnings by a significant amount, your board does need to know. In these instances, you might call the board chairman first and decide if calling individual board members is appropriate. If you wait for the meeting, the board might pepper you with questions you're not prepared to answer. At the very least, you'll be in the hot seat for your unwelcome surprise. If you talk to board members individually in advance and explain what went wrong and how you intend to fix it (take responsibility), you have a better chance of having a more productive board meeting that is focused on moving forward rather than on beating you up for what went wrong.

\section{Don't limit your contact with the board to formal meetings.}

Some of the best guidance and help comes from contact between meetings. Your board wants you to succeed, so great board members will be happy to take a call outside a formal board meeting to give advice. The board chairperson or lead director (when the CEO is also the chairperson) is often chosen based on his or her ability to be an effective sounding board for the CEO as well as represent the position of the board. CEOs should consult outside of regular meetings with board members with specific expertise-industry, financial, marketing - who might help solve a problem. These informal meetings are typically conducted by phone, or in person if the board member is local.

\section{Don't forget the minutes.}

You are legally required to take minutes at meetings of the board. However, keep in mind that these minutes are legal documents that are discoverable in the event of an investigation or lawsuit. Therefore, only state the facts and avoid associating particular members with topics or speculation. It's quite common to have your attorney on hand at these meetings to keep the minutes.

\section{Get Coaching to Work Productively}

New CEOs, as well as experienced ones who want to improve their board management skills, can benefit from the coaching that a qualified business consultant can provide. A consultant can quickly identify communication problems and suggest ways to resolve them. Inexperienced CEOs often want the board to be their cheerleader, supporting everything they do without question. That is not the purpose of the board -- its purpose is to represent the interests of the shareholders and to work with management to ensure that those interests are respected. A consultant can help a new CEO navigate the intricacies of this very complex relationship. When selecting a consultant, it's important to hire someone who has experience and can be trusted to maintain the confidentiality of the relationship. Your attorneys, auditors or board members can usually help you identify the best person for the job.

Your board should be one of your company's most important assets. Use it wisely and you'll actually look forward to board meetings.

Additional Search Terms: strategy, entrepreneurship, advisors, mentors, legal issues, law 